\title{
Pengaruh Pelapisan Gel Lidah Buaya dengan Campuran Asam Askorbat dan Kalium Sorbat terhadap Susut Bobot, pH dan Organoleptik Buah Melon Potong Segar.
}

\section{Effect of Aloe Vera Gel Coating with a Mix of Ascorbic Acid and Potassium Sorbate on Weight Loss, $p H$ and Organoleptic of Fresh-Cut Melons.}

\author{
Ni Wayan Sulasmi, I Made Supartha Utama*, I Gusti Ketut Arya Arthawan \\ Program Studi Teknik Pertanian dan Biosistem, Fakultas Teknologi Pertanian Universitas Udayana, \\ Badung, Bali, Indonesia \\ *email: supartha_utama@unud.ac.id
}

\begin{abstract}
Abstrak
Buah melon yang telah mengalami pengolahan minimal memiliki sifat mudah rusak (perishable) dengan masa simpan yang relative singkat. Penelitian ini bertujuan untuk mengatahui pengaruh pelapisan gel lidah buaya dengan campuran asam askorbat dan kalium sorbat terhadap susut bobot, $\mathrm{pH}$ dan organoleptik buah melon potong segar atau proses minimal. Penelitian menggunakan Rancangan Acak Lengkap (RAL) terdiri dari dua faktor perlakuan yaitu konsentrasi asam askorbat $(0 \%, 1.5 \%$ dan $3 \%)$ dan kalium sorbat $(0 \%, 0.2 \%$ dan $0.4 \%$ ). Percobaan ini diulang sebanyak tiga kali dengan suhu penyimpanan $5 \pm 2{ }^{\circ} \mathrm{C}$. Hasil penelitian menunjukkan asam askorbat dan kalium sorbat berpengaruh nyata terhadap nilai susut bobot, $\mathrm{pH}$ dan atribut organoleptik buah melon potong segar. Asam askorbat dan kalium sorbat mampu menghambat kehilangan bobot, mempertahankan nilai organoleptik dan menurunkan nilai $\mathrm{pH}$ sehingga aktivitas pertumbuhan jamur dan kapang terhambat pada buah potong tersebut. Gel lidah buaya dengan penambahan asam askorbat 3\% dan kalium sorbat $0,2 \%$ merupakan perlakuan yang memberikan nilai atribut organoleptik terbaik selama penyimpanan. Kombinasi ini mampu mempertahankan nilai warna dan tekstur hingga hari ke 14 serta mempertahankan aroma hingga hari ke 10.
\end{abstract}

Kata kunci: buah melon potong segar, asam askorbat, kalium sorbat, aloe vera, organoleptik

\begin{abstract}
Melon fruit which is undergoing a minimal process is easy to damage (perishable) with short shelf life. This study aims to determine the effect of coating aloe vera gel with a mixture of ascorbic acid and potassium sorbate on weight loss, $\mathrm{pH}$, and organoleptic of fresh-cut melons. This study using a completely randomized design (CRD comprised two treatment factors, namely ascorbic acid $(0 \%, 1.5 \%$ and $3 \%)$ and potassium sorbate $(0 \%, 0.2 \%$ and $0.4 \%))$. The experiment was replicated three times with a storage temperature of $5 \pm$ $2{ }^{\circ} \mathrm{C}$. The results showed that ascorbic acid and potassium sorbate significantly affected the weight loss, $\mathrm{pH}$, and organoleptic values of fresh-cut melons. Ascorbic acid and potassium sorbate can inhibit weight loss, maintain organoleptic values, and reduce the $\mathrm{pH}$ value of fresh-cut melons so that the activity of fungal and mold growth is inhibited. Aloe vera gel with the addition of $3 \%$ ascorbic acid and $0.2 \%$ potassium sorbate was the treatment that gave the best organoleptic value during storage. This combination can maintain the value of color and texture up to day 14 and maintain aroma until day 10.
\end{abstract}

Keywords: fresh-cut melon, ascorbic acid, potassium sorbate, aloe vera, organoleptic

\section{PENDAHULUAN}

Buah potong segar adalah salah satu jenis produk terolah minimal yang banyak dijual di supermarket. Buah potong segar banyak diminati masyarakat karena lebih praktis untuk dikonsumsi. Salah satu buah yang banyak dijual dalam bentuk buah potong segar adalah buah melon. Buah melon potong segar memiliki nilai jual yang lebih tinggi jika dibandingkan dengan buah potong lain seperti papaya dan semangka. Di Indonesia, angka produksi buah melon di Indonesia terus mengalami peningkatan dari 92,434-ton ditahun 2017 dan pada tahun 2019 mencapai 122,482-ton pertahun (BPS, 2019). Buah-buahan dan sayuran potong segar dengan $\mathrm{pH}$ tinggi $(>4.6)$ dan aktivitas air $(\mathrm{aw}>0.85)$ dianggap sangat mudah rusak (perishable) jika tidak mengalami proses pengawetan yang menunda perubahan biologis dan biokimia yang tidak diinginkan (Barrett et al., 2010). Buah melon potong memiliki nilai $\mathrm{pH}$ berkisar antara 6-7 dengan kandungan air yang tinggi, sehingga buah melon potong cepat mengalami kerusakan. 
Buah melon potong segar umur simpan yang sangat singkat jika dibandingkan dengan buah dan sayuran utuh, hal ini terjadi akibat kerusakan fisiologis pada buah. Kerusakan akan semakin cepat apabila adanya pelukaan pada jaringan buah (Salem \& Kassem, 2018). Buah potong segar mengalami kemunduran mutu yang lebih cepat akibat peningkatan laju respirasi dan produksi etilen dan konsumsi gula, lipid dan asam organik mempercepat proses pematangan (Olivas et al ., 2003). Perubahan yang terjadi pada buah dapat menyebabkan hilangnya rasa, perubahan warna, pelunakan, kehilangan vitamin serta umur simpan yang lebih pendek (Kader, 2013). Selain itu, peningkatan aktivitas respirasi dan transpirasi berakibat pada kehilangan bobot buah. Susut bobot sebagai salah satu faktor yang digunakan untuk mengidentifikasi mutu fisik buah. semakin tinggi nilai kehilangan bobot, maka tingkat kesegaran buah semakin kecil (Darmajana, 2017). Selain perubahan bobot, selama penyimpanan buah juga akan mengalami perubahan komponen kimia yang dapat dillihat dari nilai derajat keasaman $(\mathrm{pH})$. Penanganan yang dapat dilakukan untuk mempertahankan mutu buah melon potong segar adalah dengan mengaplikasikan bahan pelapis yang dapat dimakan berbahan dasar lidah buaya (Raghav et al., 2016).

Lidah buaya tergolong kedalam jenis bahan polisakarida yang memiliki sifat anti mikroba, pembentuk biodegrabilitas dan aman untuk dikonsumsi (Misir et al ., 2014). Menurut Marwina et al., (2016) konsentrasi terbaik gel lidah buaya untuk menghambat kerusakan tomat selama penyimpanan dingin $\left(10^{\circ} \mathrm{C}\right)$ adalah $30 \%$. Lidah buaya mengandung berbagai jenis zat yang dapat membantu dalam proses pengawetan produk buah segar. Selain memiliki keunggulan sebagai bahan pelapis, gel lidah buaya juga memiliki kekurangan yaitu memiliki sifat yang mudah berubah warna (Suriati et al ., 2020).. Dari hasil penelitian pendahuluan, gel lidah buaya yang disimpan dalam suhu ruang mengalami perubahan warna setelah 1 hari penyimpanan. Antioksidan, antimikroba dan stabilisator lainnya dapat ditambahkan pada gel lidah buaya untuk menstabilkan gel. Kombinasi antara asam akorbat, kalium sorbat dan gel lidah buaya dapat menghambat kerusakan buah jambu potong segar hingga hari ke 12 (Nasution et al ., 2015).

Kalium sorbat sebagai anti jamur berfungsi untuk menghambat pertumbuhan kapang dan jamur pada permukaan buah. kalium sorbat memiliki sifat yang bekerja maksimal pada kondisi $\mathrm{pH}<6.5$, sehingga kombinasi dengan asam askorbat dapat saling menunjang. Asam askorbat sebagai antioksidan berfungsi untuk menghambat oksidasi degradasi warna dan reaksi lainnya Selain itu, asam askorbat juga berfungsi untuk menurunkan $\mathrm{pH}$ larutan agar kalium sorbat yang dikombinasikan dapat bekerja maksimal. Penelitian ini bertujuan untuk mengetahui pengaruh asam askorbat dan kalium sorbat terhadap nilai susut bobot, $\mathrm{pH}$ dan Organoleptik buah melon potong segar selama penyimpanan dingin.

\section{METODE}

\section{Tempat dan Waktu Penelitian}

Penelitian ini dilakukan pada bulan JuliAgustus 2020 di Laboratorium Teknik Pascapanen, Gedung Agrokomplek, Fakultas Teknologi Pertanian, Universitas Udayana.

\section{Bahan dan Alat Penelitian}

Alat yang digunakan dalam penelitian ini yaitu timbangan digital (merk Adventure TM Pro Av 8101, USA), pH meter (merk Senz Digital pH Tester, Singapore), blender, thermometer, keranjang, talenan plastik, gelas beaker, baskom, saringan, kompor, panci, corong, biuret, Erlenmeyer, nampan, labu ukur, sarung tangan, pipet tetes, gelas plastik, sendok, spatula, batang pengaduk, pisau, parutan, label, alat penyimpanan dingin (showcase).

Bahan utama yang digunakan dalam penelitian ini adalah buah melon putih (Cucumis melo L. var Reticulatus) dengan kriteria intensitas jala kasar penuh dipermukaan kulit buah dan dipanen 3 hari sebelum diolah minimal dan diberikan perlakuan. ukuran buah melon berkisar antara 14-16 cm dengan berat 2-2,5 kg didapatkan dari petani di daerah Padangsambian, Mengwi Badung. Selain buah melon, daun lidah buaya sebagai bahan utama pelapis didapatkan petani di daerah Besakih, Karangasem, Bali.

\section{Rancangan Percobaan}

Penelitian ini menggunakan rancangan acak lengkap (RAL) dua faktor dengan masing-masing tiga taraf konsentrasi yaitu asam askorbat $(0 \%, 1.5 \%, 3 \%)$ dan kalium sorbat $(0 \%, 0.2 \%, 0.4 \%)$ dalam gel lidah buaya konsentrasi $30 \%$. Percobaan ini diulang sebanyak tiga kali. Buah yang telah diberikan perlakuan dikemas dalam tray stayrofoam dan ditutup stretching plastik kemudian buah disimpan pada suhu $\left(5 \pm 2{ }^{\circ} \mathrm{C}\right)$ (Nasution et al ., 2015). Data hasil pengamatan dianalisis secara statistik dengan Uji ANOVA (Analysis of Variance) dan apabila perlakuan signifikan maka dilanjutkan dengan $U j i$ Duncan's Multiple Range Test (DMRT) menggunakan aplikasi IBM Statistic SPSS 26.

\section{Persiapan Bahan Pelapis}

Sebelum digunakan daun lidah buaya dicuci dengan air mengalir untuk membersihkan kotoran pada bagian luar daun kemudian direndam dalam posisi 
berdiri menggunakan larutan klorin konsentrasi 200 ppm selama 30 menit (Suriati et al ., 2020).. Daun lidah buaya dibersihkan kemudian diambil bagian daging buah yang berwarna bening lalu dicuci menggunakan air matang untuk memaksimalkan pembersihan yellowsap gel lidah buaya. Daging daung lidah buaya dihancurkan menggunakan blender ( 5 menit) kemudian disaring. Lidah buaya yang sudah disaring kemudian dipanaskan hingga mencapai suhu $70^{\circ} \mathrm{C}$ selama 5 menit. Lalu tambahkan asam askorbat dan kalium sorbat sesuai konsentrasi kemudian saring. Gel lidah buaya dibiarkan dalam suhu ruang selama 1-2 jam, setelah dingin gel diencerkan menjadi 30\% lalu disaring kembali. Gel dikatakan stabil apabila tidak mengalami perubahan warna menjadi merah muda, kuning ataupun kecoklatan. (Suriati et al ., 2018).

\section{Pelapisan Pada Buah Melon Fresh-cut}

Buah melon dipisahkan dari kulitnya kemudian dipotong menjadi ukuran $2 \times 2 \times 3 \mathrm{~cm}$ lalu dicuci menggunakan air. Buah melon yang telah dipotong dicelupkan pada larutan pelapis selama 2 menit kemudian ditiriskan hingga tidak menetes. Buah dikemas dalam tray stayrofoam dan ditutup stretching plastik kemudian buah disimpan pada suhu $(5 \pm 2 \circ \mathrm{C})$

\section{Pengamatan}

Pada penelitian ini dilakukan pengamatan terhadap nilai susut bobot, $\mathrm{pH}$ dan organoleptik yang meliputi mutu visual, tekstur, aroma dan penerimaan keseluruhan terhadap buah melon potong segar. Pengamatan dilakuan setiap 2 hari sekali hingga hari ke 14 atau hingga mencapai batas maksimal kerusakan.

\section{Parameter yang Diamati \\ Susut bobot}

Nilai susut bobot diperoleh dengan membandingkan berat buah pada hari ke-n dengan berat buah pada hari ke-(n-1). Pengukuran susut bobot dilakukan penimbangan pada buah menggunakan timbangan analitik dengan satuan gram. Hasil nilai susut bobot dinyatakan dalam persen yang dihitung dengan Persamaan berikut.(Alhassan \& Abdul-rahaman, 2014).

Keterangan:

$$
\text { Susut Bobot }(\%)=\frac{w_{(n-1)}-w_{n}}{w_{(n-1)}} \times 100 \%
$$

$\mathrm{W}_{\mathrm{n}}=$ berat buah pada pengamatan ke-n

$\mathrm{W}_{\mathrm{n}-1}=$ berat buah pada pengamatan ke-n-1

\section{Derajat Keasaman}

Pengukuran nilai derajat keasaman dilakukan dengan menggunakan alat $\mathrm{pH}$ meter (merk Senz Digital $\mathrm{pH}$ Tester). Buah dihancurkan kemudian alat dicelupkan dan dibiarkan hingga stabil. Nilai pH dilihat melalui display alat yang berupa angka (Nurhayati et al., 2014)

\section{Organoleptik}

Uji organoleptik dilakukan oleh 15 orang panelis. Penilaian menggunakan uji skoring pada mutu visual, tekstur dan aroma serta uji kesukaan untuk penerimaan keseluruhan dengan rentang nilai 1-5 sesuai kriteria mutu masing-masing (Nurhayati et al., 2014).

\section{HASIL DAN PEMBAHASAN}

\section{Susut Bobot}

Berdasarkan hasil analisis keragaman data menunjukkan bahwa interaksi antara asam askorbat dan kalium sorbat tidak berpengaruh nyata $(\mathrm{P}>0.05)$ pada hari ke 2, 6, 8, 10, 12 dan 14. Interaksi antara asam askorbat dan kalium sorbat berpengaruh nyata $(\mathrm{P}<0.05)$ pada hari ke 4, sedangkan kalium sorbat secara tunggal berpengaruh nyata $(\mathrm{P}<0.05)$ pada hari ke 10 maka dilakukan uji lanjut DMRT untuk mengetahui perbedaan nyata antar perlakuan. Perbedaan nyata antar perlakuan ditunjukkan oleh notasi di belakang angka.

Tabel 1. Pengaruh asam askorbat dan kalium sorbat terhadap susut bobot buah melon potong segar

\begin{tabular}{llll}
\multicolumn{4}{c}{ Susut Bobot (\%) } \\
Hari ke-4 & \multicolumn{3}{c}{ Hari ke-10 } \\
A0K0 & $0.910^{\mathrm{ab}}$ & $\mathrm{K} 0$ & $0.3788^{\mathrm{ab}}$ \\
$\mathrm{A} 0 \mathrm{~K} 1$ & $0.828^{\mathrm{bc}}$ & $\mathrm{K} 1$ & $0.3161^{\mathrm{bc}}$ \\
A0K2 & $1.156^{\mathrm{a}}$ & $\mathrm{K} 2$ & $0.1774^{\mathrm{c}}$ \\
A1K0 & $0.638^{\mathrm{cd}}$ & Kontrol & $0.5153^{\mathrm{a}}$ \\
A1K1 & $0.602^{\text {cd }}$ & - & - \\
A1K2 & $0.536^{\mathrm{d}}$ & - & - \\
A2K0 & $1.117^{\mathrm{a}}$ & - & - \\
A2K1 & $0.668^{\mathrm{bcd}}$ & - & - \\
A2K2 & $0.634^{\mathrm{cd}}$ & - & - \\
Kontrol & $1.151^{\mathrm{a}}$ & - & - \\
\hline Interaksi & $\mathrm{A} \quad$ dan & $\mathrm{K}$ & \multicolumn{2}{c}{ K berpengaruh nyata } \\
berpengaruh nyata & &
\end{tabular}

Keterangan: A0, A1 dan A2 berturut-turut menunjukkan Asam Askorbat $0 \%, 1.5 \% 3 \%$, dan K0, K1 dan K2 berturut-turut menunjukkan kalium sorbat $0 \%, 0.2 \%$ $0.4 \%$.

Berdasarkan hasil uji DMRT pada Tabel 1. Buah melon potong segar dengan pelapis memiliki nilai susut bobot yang lebih rendah dibandingkan dengan buah melon tanpa pelapis. Hal ini terjadi karena pada perlakuan kontrol tidak diberikan pelapisan sehingga lebih cepat mengalami proses transpirasi. Selama penyimpanan, terdapat embun didalam kemasan buah melon potong segar, hal ini menunjukkan bahwa adanya proses penguapan air. Buah melon potong segar masih tetap mengalami proses respirasi dan transpirasi selama penyimpanan yang dapat 
menyebabkan kehilangan bobot karena kandungan air pada buah telah berkurang.

Perlakuan A1K2 (asam askorbat 1.5\%, kalium sorbat $0.4 \%$ ) memiliki nilai susut bobot terendah sebab asam askorbat sebagai antioksidan mampu menghambat proses oksidasi yang akan mengubah asam askorbat menjadi asam dehidroaskorbat sehingga kehilangan air melalui proses transpirasi dan respirasi pada buah dapat dihambat (Oms-oliu et al., 2009). Keberadaan kalium sorbat mampu menghambat pertumbuhan jamur pada permukaan buah sehingga kerusakan dan kehilangan air akibat jamur dapat terhambat. Pertumbuhan jamur pada permukaan buah mempercepat kehilangan air (Nasution et al., 2015)..

\section{pH}

Derajat keasaman $(\mathrm{pH})$ merupakan nilai yang digunakan untuk menyatakan tingkat keasaman atau basa yang dimiliki oleh suatu zat, larutan atau benda. Pada buah segar, nilai $\mathrm{pH}$ digunakan sebagai tanda vital rasa pada buah. Berdasarkan hasil analisis keragaman data menunjukkan bahwa interaksi antara asam askorbat dan kalium sorbat berpengaruh nyata $(\mathrm{P}<0.05) 12$ dan 14 terhadap nilai derajat keasaman pada hari ke sedangkan asama askorbat secara tunggal berpengaruh nyata $(\mathrm{P}<0.05)$ pada hari ke 2 , 4, 6, 8 dan 10 maka dilakukan uji lanjut DMRT untuk mengetahui perbedaan nyata antar perlakuan.

Tabel 2. Pengaruh asam askorbat dan kalium sorbat terhadap Derajat Keasaman buah melon potong segar

\begin{tabular}{lll}
\multicolumn{3}{c}{ Derajat Keasaman } \\
Kode & \multicolumn{1}{c}{ Hari ke-12 } & Hari ke-14 \\
\hline A0K0 & $5,500^{\mathrm{a}}$ & $5,233^{\mathrm{a}}$ \\
A0K1 & $4,767^{\mathrm{c}}$ & $4,433^{\mathrm{c}}$ \\
A0K2 & $5,533^{\mathrm{a}}$ & $5,200^{\mathrm{a}}$ \\
A1K0 & $5,067^{\mathrm{bc}}$ & $4,866^{\mathrm{ab}}$ \\
A1K1 & $5,067^{\mathrm{bc}}$ & $4,600^{\mathrm{bc}}$ \\
A1K2 & $5,067^{\mathrm{bc}}$ & $4,433^{\mathrm{c}}$ \\
A2K0 & $5,100^{\mathrm{b}}$ & $4,667^{\mathrm{bc}}$ \\
A2K1 & $5,400^{\mathrm{ab}}$ & $5,067^{\mathrm{a}}$ \\
A2K2 & $5,167^{\mathrm{b}}$ & $4,667^{\mathrm{bc}}$ \\
Kontrol & $5,300^{\mathrm{ab}}$ & $4,633^{\mathrm{bc}}$ \\
\hline Keterangan & $\mathrm{A} 0, \mathrm{Aan} \mathrm{A}^{\mathrm{b}} \mathrm{berturut}$ & $\mathrm{curu}$ \\
\hline
\end{tabular}

Keterangan: A0, A1 dan A2 berturut-turut menunjukkan Asam Askorbat 0\%, 1.5\% 3\%, dan K0, K1 dan K2 berturut-turut menunjukkan kalium sorbat $0 \%, 0.2 \%$ $0.4 \%$.

Buah melon potong segar mengalami penurunan nilai derajat keasaman namun tidak signifikan pada setiap hari pengamatan Tabel 2 menunjukkan bahwa pada hari ke 12, perlakuan kontrol berbeda nyata dengan perlakuan $\mathrm{A} 0 \mathrm{~K} 1$ (asam askorbat $0 \%$ dan kalim sorbat $0.2 \%$ ) namun tidak berbeda nyata dengan perlakuan lainnya. Perlakuan A0K1 (asam askorbat 0\% dan kalim sorbat $0.2 \%$ ) memiliki nilai derajat keasaman yang lebih rendah dibandingkan dengan perlakuan lainnya. Hal ini diduga keberadaan asam sorbat dalam kalium sorbat, yang menyebabkan terjadinya proses metabolism yang lebih cepat. Kalium sorbat akan bekerja lebih efektif ketika berada pada kondisi dengan derajat keasaman yang lebih rendah. Perubahan derajat keasaman melon menunjukkan perubahan pada susunan cairan sel selama buah mengalami pematangan. Derajat keasaman cenderung naik seiring dengan meningkat nilai vitamin c selama penyimpanan sebagai akibat dari proses metabolism pematangan buah melon derajat keasaman. Selain itu, nilai derajat keasaman juga dipengaruhi nilai total asam yang terkandung dalam buah (Khairi et al ., 2017).

Tabel 3. Pengaruh asam askorbat dan kalium sorbat terhadap Derajat Keasaman buah melon potong segar

\begin{tabular}{llllll}
\multicolumn{5}{c}{ Derajat Keasaman } \\
Kode & $\begin{array}{l}\text { Hari } \\
\text { ke-2 }\end{array}$ & $\begin{array}{l}\text { Hari } \\
\text { ke-4 }\end{array}$ & $\begin{array}{llll}\text { Hari } \\
\text { ke-6 }\end{array}$ & $\begin{array}{l}\text { Hari } \\
\text { ke-8 }\end{array}$ & $\begin{array}{l}\text { Hari } \\
\text { ke-10 }\end{array}$ \\
\hline A0 & $6.133^{\mathrm{a}}$ & $6.033^{\mathrm{a}}$ & $5.733^{\mathrm{a}}$ & $5.944^{\mathrm{a}}$ & $5.433^{\mathrm{a}}$ \\
$\mathrm{A} 1$ & $5.755^{\mathrm{b}}$ & $5.656^{\mathrm{b}}$ & $5.267^{\mathrm{b}}$ & $5.633^{\mathrm{b}}$ & $5.000^{\mathrm{b}}$ \\
$\mathrm{A} 2$ & $5.688^{\mathrm{b}}$ & $5.567^{\mathrm{b}}$ & $5.378^{\mathrm{b}}$ & $5.711^{\mathrm{b}}$ & $5.267^{\mathrm{b}}$ \\
Kontrol & $6.233^{\mathrm{a}}$ & $6.100^{\mathrm{a}}$ & $5.800^{\mathrm{a}}$ & $5.933^{\mathrm{a}}$ & $5.400^{\mathrm{a}}$ \\
\hline
\end{tabular}

Keterangan: A0, A1 dan A2 berturut-turut menunjukkan Asam Askorbat 0\%, 1.5\%, dan 3\%

Berdasarkan hasil uji keragaman data pada Tabel 5 interaksi antara asam askorbat dan kalium sorbat berpengaruh nyata terhadap derajat keasaman buah melon potong segar pada hari ke 12 dan 14 . Menurut (Nasution et al ., 2015) keberadaan asam askorbat semakin menurunkan derajat keasaman larutan pelapis sehingga kalium sorbat dapat bekerja maksimal. Hal ini, menyebabkan peningkatan proporsi asam sorbat yang tidak terdisosiasi sehingga menghambat pertumbuhan jamur. Terhambatnya pertumbuhan jamur, dapat menghambat fermentasi terjadi pada buah yang mengakibatkan penurunan derajat keasaman.

Asam askorbat berpengaruh secara tunggal terhadap nilai derajat keasaman buah melon potong segar. Perlakuan kontrol berbeda secara nyata dengan perlakuan A0 (asam askorbat $0 \%$ ) tetapi berbeda nyata dengan perlakuan A1 (asam askorbat $1.5 \%$ ) dan A2 (asam askorbat 3\%). Hal ini sesuai dengan hasil penelitian (Nasution et al ., 2015) buah jambu potong yang diberi perlakuan pelapis dengan penambahan asam askorat memiliki nilai derajat keasaman yang lebih rendah. Hal ini disebabkan penambahan asam organik seperti asam askorbat meningkatkan konsentrasi proton yang menyebabkan peningkatan derajat keasaman.

\section{Organoleptik Mutu Visual Buah}


Penilaian mutu visual dilakukan uji skoring buah melon potong segar dengan skor 1 = Warna hijau kecoklatan, berlendir, berjamur,

Organoleptik Mutu Visual

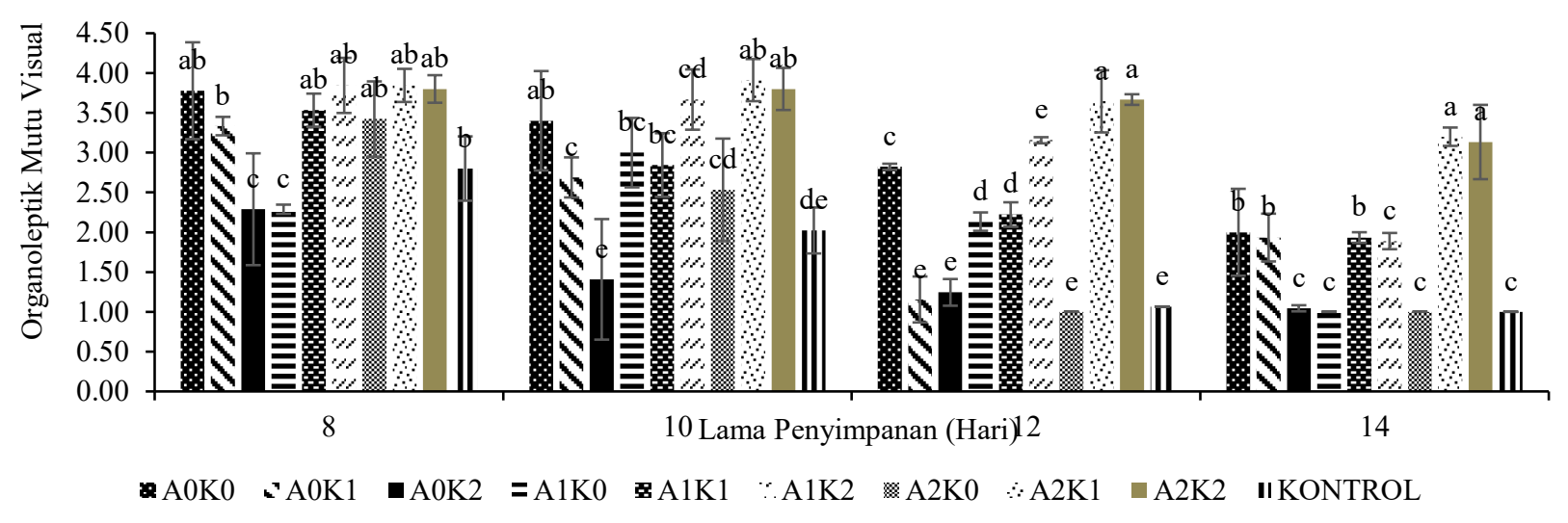

Gambar 1. Pengaruh asam askorbat dan kalium sorbat terhadap Organoleptik Mutu Visual buah melon potong segar.

$2=$ Warna hijau pucat - kuning kecoklatan, berlendir, $3=$ Warna hijau pucat-kuning muda, mulai berair, 4 = Warna hijau pucat-putih, permukaan sedikit kering dan $5=$ Warna hijau segar-putih, permukaan nampak lembab.

Berdasarkan hasil analisis keragaman data, interaksi asam askorbat dan kalium sorbat berpengaruh nyata $(\mathrm{P}<0.05)$ terhadap penilaian organoleptik mutu visual buah melon potong segar pada hari ke 8, 10, 12 dan 14. Hal ini menunjukkan bahwa terjadi perubahan mutu visual yang berbeda pada tiap perlakuan. Selama Penyimpanan, perlakuan kontrol memiliki nilai yang lebih rendah dibandingkan dengan buah melon potong segar yang diberi pelapis. Perlakuan kontrol pada hari ke 8, telah mengalami perubahan warna menjadi kuning kecoklatan dan berair serta mulai timbul lendir dan jamur pada permukaan buah. Perubahan warna buah dari hijau menjadi kekuningan dikarenakan terjadi degradasi khlorofil akibat perubahan $\mathrm{pH}$, perubahan enzim oksidatif dan adanya enzim khlorofilase. Degradasi warna hijau yang terjadi menyebabkan munculnya warna lain seperti warna kuning (xanthofil). (Sudjatha \& Wisaniyasa, 2017).

Berdasarkan hasil uji DMRT pada Gambar 1, perlakuan A2K1 ((asam askorbat 3\% dan kalium sorbat $0.2 \%$, memiliki nilai tertinggi selama penyimpan. Hal ini dikarenakan buah masih memiliki warna hijau yang cerah selama penyimpanan dan mengalami perubahan warna kecoklatan yang lebih lambat. Perlakuan A2K1 (asam askorbat $3 \%$ dan kalium sorbat $0.2 \%$ ), menghambat perubahan warna pada buah. Asam askorbat yang berfungsi sebagai agen anti browning yang mengurangi kuinon yang dihasilkan oleh oksidasi polifenol kembali ke substrat fenolik. Kalium sorbat mampu mencegah pertumbuhan jamur dan kapang hingga hari ke 14, sehingga proses pembusukan buah dihambat.

\section{Organoleptik Tekstur Buah}

Penilaian tekstur buah melon potong segar dengan skor 1 = sangat lunak, $2=$ lunak, 3 = agak renyah/agak lunak, $4=$ renyah/agak keras dan $5=$ sangat renyah/keras. Berdasarkan hasil analisis ragam, interaksi asam askorbat dan kalium sorbat berpengaruh nyata $(\mathrm{P}<0.05)$ terhadap penilaian organoleptik tekstur buah melon potong segar pada hari ke 6, 8, 10, 12 dan 14. Berdasarkan hasil penilaian panelis, buah melon potong segar mengalami penurunan nilai selama penyimpanan. Perubahan tekstur yang terjadi pada perlakuan berbeda-beda pada hari tertentu.

Berdasarkan hasil analisis keragaman pada, nilai organoleptik tekstur buah melon potong segar interaksi asam askorbat dan kalium sorbat berpengaruh nyata $(\mathrm{P}<0.05)$ pada hari ke $6,8,10,12$ dan 14. Buah melon potong segar tanpa pelapis memiliki nilai terendah selama penyimpanan. Hal ini menunjukkan bahwa perubahan tekstur pada buah tanpa pelapis berlangsung lebih cepat. Perubahan tekstur buah ini disebabkan oleh degradasi hemiselulosa dan perubahan propektin menjadi pektin yang larut dalam air sehingga pektin yang larut menyebabkan turgor sel berkurang (Sudjatha \& Wisaniyasa, 2017). Pelapis pada buah melon potong 
segar efektif untuk menghambat perombakan pektin dengan menghambat respirasi dan transpirasi pada buah.

Berdasarkan hasil uji lanjut DMRT, perlakuan A2K1 (asam askorbat 3\% dan kalium sorbat $0.2 \%$ ), memiliki nilai tekstur lebih tinggi dibandingkan perlakuan lainnya. Pada awal penyimpanan asam askorbat dan kalium sorbat dalam pelapis mampu memperlambat laju kehilangan air akibat respirasi dan tranpirasi sehingga tidak terjadi perubahan yang signifikan. Sedangkan keberadaan kalium sorbat sebagai agen anti jamur mampu menghambat pertumbuhan jamur yang juga dapat mempercepat kerusakan jaringan. Dengan konsentrasi asam yang lebih tinggi, mampu memaksimalkan kinerja kalium sorbat karena asam askorbat lebih efektif ketika berada dalam $\mathrm{pH}$ yang rendah. Selain itu, nilai $\mathrm{pH}$ yang rendah juga menghambat pertumbuhan jamur dan kapang (Nasution et al ., 2015).

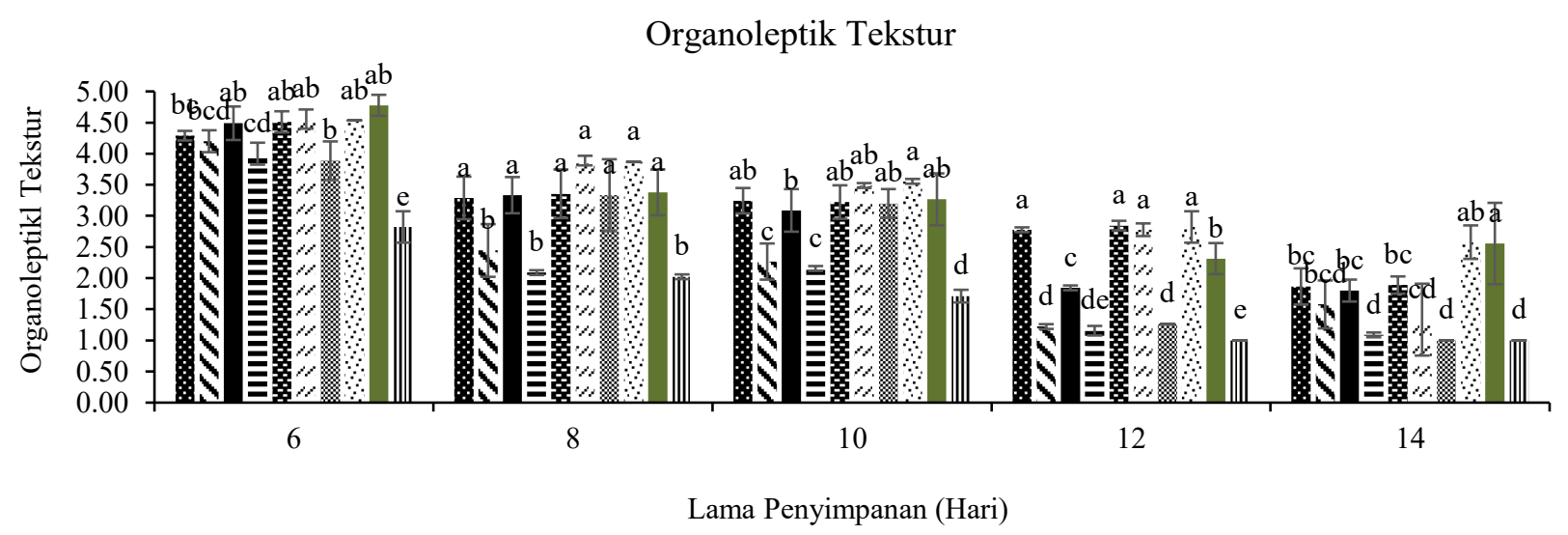

口A0K0 、A0K1 -A0K2 = A1K0

Gambar 2. Pengaruh asam askorbat dan kalium sorbat terhadap organoleptik tekstur buah melon potong segar.

\section{Organoleptik Aroma Buah}

Penilaian aroma buah melon potong segar dengan skor $1=$ tengik/busuk menyengat, $2=$ asam $/$ basi, $3=$ khas, ranum sedikit asam/basi., $4=$ khas, ranum (wangi manis), normal dan 5 = sangat khas, ranum (wangi manis), normal. Berdasarkan hasil analisis ragam, interaksi asam askorbat dan kalium sorbat berpengaruh nyata $(\mathrm{P}<0.05)$ terhadap penilaian organoleptik aroma buah melon potong segar pada hari ke 8, 10, 12 dan 14.

Gambar 3 menunjukkan bahwa perubahan signifikan terjadi pada buah pada hari ke 8 . Pada perlakuan tertentu buah mulai mengalami perubahan aroma menjadi sedikit asam. Dari hasil penilaian panelis perlakuan A1K0 (asam 1.5\% dan kalium sorbat $0 \%$ ) memiliki nilai terendah dan tidak berbeda nyata dengan perlakuan kontrol. Perubahan aroma dapat disebabkan kerusakan mikrobiologis yang mengubah karbohidrat dan protein menjadi senyawa lain yang dapat memberikan aroma dan rasa yang kurang menarik. Perubahan aroma yang terjadi pada buah juga disebabkan oleh sintesis yang terjadi pada substrat buah sebagai hasil dari siklus Krebs yaitu fenol yang merupakan zat aromatis dan volatile (Sudjatha \& Wisaniyasa, 2017).

Berdasarkan hasil uji DMRT pada Gambar 3, perlakuan A2K1 (asam askorbat 3\% dan kalium sorbat $0.2 \%$ ) memiliki nilai organoleptik aroma yang cukup stabil hingga hari ke 10 kemudian mengalami penurunan di hari berikutnya. Hal ini menunjukkan bahwa aroma buah melon potong segar dengan pelapis A2K1 (asam askorbat 3\% dan kalium sorbat $0.2 \%$ ) baru mengalami perubahan aroma menjadi sedikit asam di hari ke 10 dan semakin asam di hari berikutnya. Pelapis A2K1 (asam askorbat 3\% dan kalium sorbat $0.2 \%$ ) mampu mempertahankan aroma buah hingga hari ke 10 penyimpanan 


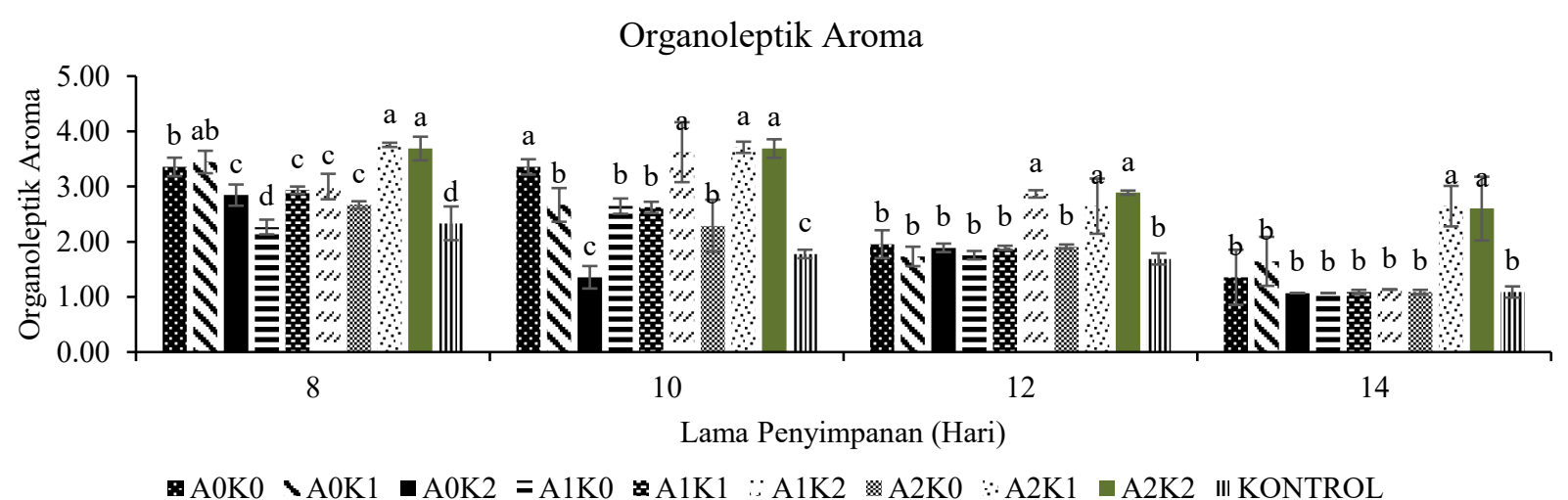

Gambar 3. Pengaruh asam askorbat dan kalium sorbat terhadap organoleptik aroma buah melon potong segar

\section{Organoleptik Penerimaan Keseluruhan Buah}

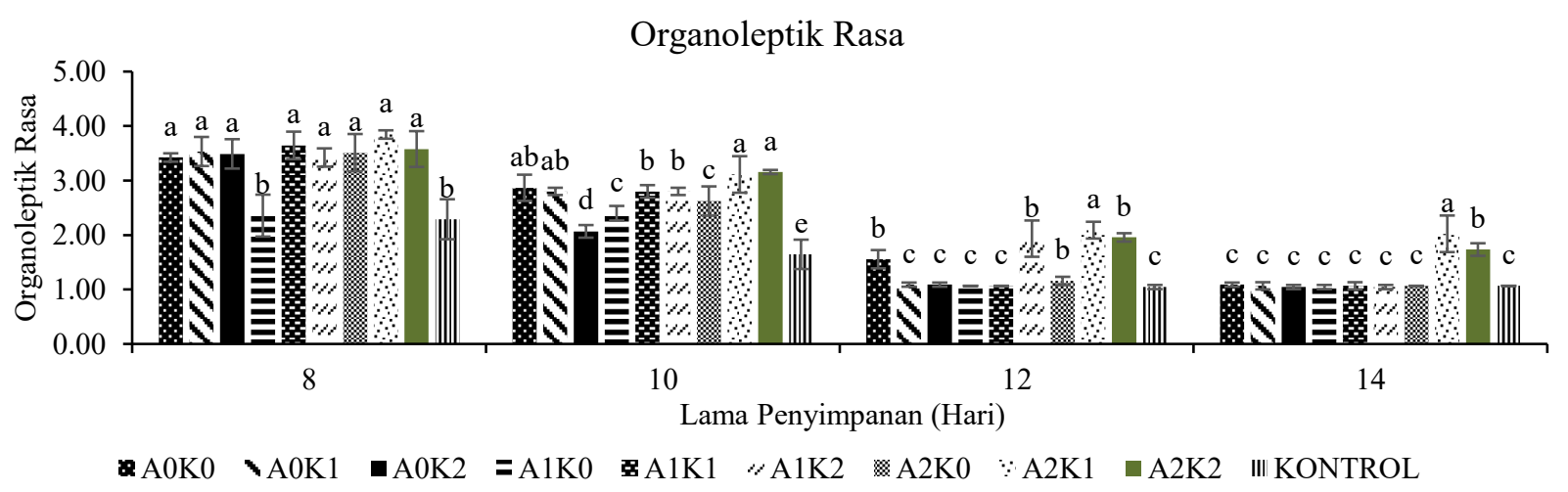

Gambar 4. Pengaruh asam askorbat dan kalium sorbat terhadap organoleptik peneriman keseluruhan buah melon potong segar

Penilaian penerimaan keseluruhan dilakukan dengan uji kesukaan buah melon potong segar dengan skor 1 $=$ sangat tidak suka, 2 = tidak suka, $3=$ biasa, $4=$ suka dan 5 = sangat suka. Berdasarkan hasil analisis ragam, interaksi asam askorbat dan kalium sorbat berpengaruh nyata $(\mathrm{P}<0.05)$ terhadap penilaian organoleptik rasa buah melon potong segar pada hari ke 6, 10, 12 dan 14. Gambar 4 menunjukkan bahwa hingga hari ke 6 rata-rata perlakuan masih disukai oleh panelis dengan nilai terendah pada perlakuan kontrol. Perlakuan kontrol memiliki nilai terendah selama penyimpanan, hal ini dikarenakan penurunan mutu pada buah melon potong segar tanpa pelapis terjadi lebih cepat akibat kerusakan dinding sel pada jaringan.

Pada hari ke 8, buah melon tanpa pelapis mulai tidak disukai oleh panelis. Hal ini diguda karena buah telah mengalami perubahan warna menjadi kekuningan, tekstur yang sudah mulai lunak serta timbulnya aroma dan rasa asam pada buah melon potong segar. Hal ini sesuai dengan hasil pengukuran nilai color difference, perlakuan kontrol memiliki nlai tertinggi selama penyimpanan. Perlakuan kontrol juga mengalami degradasi warna yang lebih cepat sehingga buah mengalami browning enzimatis akibat respirasi aerob yang terjadi. Kemudian tidak adanya anti jamur pada permukaan buah, menyebabkan buah terserang jamur sehingga mengurangi skor penilaian dari panelis

Berdasarkan hasil uji pada Gambar 4, buah melon potong segar dengan perlakuan A2K1 (asam askorbat $3 \%$, kalium sorbat $0.2 \%$ ) pada hari ke 10 paling disukai oleh panelis. Hal ini dikarenakan, buah masih memiliki warna yang menarik, aroma yang normal serta rasa yang masih dapat diterima. Buah juga belum mengalami infeksi jamur sehingga masih sangat menarik bagi panelis. Perlakuan A2K1 (asam askorbat $3 \%$, kalium sorbat $0.2 \%$ ) memiliki nilai biasa yang artinya buah masih dapat diterima hingga hari ke 10 pada suhu penyimpanan $5^{\circ} \mathrm{C}$.

\section{KESIMPULAN}

Selama penyimpanan nilai kombinasi asam askorbat dan kalium sorbat mampu menghambat penurunan bobot dan mempertahankan nilai organoleptik baik 
pada mutu visual, tekstur, aroma dan penerimaan keseluruhan. Kombinasi asam askorbat dan kalium sorbat juga mampu menurunkan nilai $\mathrm{pH}$ sehingga pertumbuhan kapang dan jamur juga terhambat. Gel lidah buaya dengan penambahan asam askorbat 3\% dan kalium sorbat $0,2 \%$ merupakan perlakuan yang memberikan nilai organoleptik terbaik selama penyimpanan. Kombinasi ini mampu mempertahan kan nilai warna dan tekstur hingga hari ke 14 serta mempertahankan aroma hingga hari ke 10.

\section{Saran}

Berdasarkan hasil penelitian, untuk mendapatkan buah melon potong segar dengan masa simpan yang lebih lama, dapat dilakukan pelapisan dengan kombinasi asam askorbat, kalium sorbat dan gel lidah buaya. Selain itu diperlukan penelitian lanjutan untuk mengetahui potensi pertumbuhan mikroba dengan melakukan uji mikrobiologi seperti TPC.

\section{DAFTAR PUSTAKA}

Alhassan, N., and Abdul-rahaman, A. 2014. Technology And Application Of Edible Coatings For Reduction Of Losses And Extension Of Shelf Life Of Cantaloupe Melon Fruits. 3(11): 7-12.

Barrett, D. M., Beaulieu, J. C., \& Shewfelt, R. 2010. Color, flavor, texture, and nutritional quality of fresh-cut fruits and vegetables: Desirable levels, instrumental and sensory measurement, and the effects of processing. Critical Reviews in Food Science and Nutrition, 50(5),:369-389.

BPS. (019. Produksi Tanaman Buah-buahan. In Badan Pusat Statistik. https://www.bps.go.id

Darmajana, D. 2017. Pengaruh Pelapis Dapat Dimakan dari Karagenan terhadap Mutu Melon Potong dalam Penyimpanan Dingin Effects of Carrageenan Edible Coating on Fresh Cut Melon Quality in Cold Storage Doddy Andy Darmajana*, Nok Afifah, Enny Solihah, Novita Indriyanti. Agritech, 37(3): 280-287.

Kader, A. A. 2013. Postharvest Technology of Horticultural Crops - An Overview from Farm to Fork. Journal of Applied Sciences and Technology, 1(1): 1-8.

Khairi, A. N., Falah, A. F., \& Pamungkas, A. P. 2017. Analisis Mutu Pascapanen Melon (Cucumis melo L.) Kultivar Glamour Sakata Selama Penyimpanan. CHEMICA: Jurnal Teknik Kimia, 4(2): 47-52.

Marwina, R., Agustina, R., \& Putra, B. S. 2016. Perubahan Mutu Tomat (Lycopersicon esculentum Mill.) Dengan Variasi Konsentrasi Pelapisan Gel Lidah Buaya (Aloe vera L.) Dan Suhu Penyimpanan. Jurnal Ilmiah Mahasiswa Pertanian, 1(1): 985-994.

Misir, J., H. Brishti, F., \& M. Hoque, M. 2014. Aloe vera gel as a Novel Edible Coating for Fresh Fruits: A Review. American Journal of Food Science and Technology, 2(3): 93-97.

Nasution, Z., Ye, J. N. W., \& Hamzah, Y. 2015. Characteristics of fresh-cut guava coated with aloe vera gel as affected by different additives. Kasetsart Journal - Natural Science, 49(1): 111121.

Nurhayati, Hanum, T., Rangga, A., \& Husniati. 2014. Optimasi Pelapisan Kitosan Untuk Meningkatkan Masa Simpan Produk BuahBuahan Segar Potong. Jurnal Teknologi Industri Dan Hasil Pertanian, 19(2):161-178.

Olivas, G. I., Rodriguez, J. J., \& Barbosa-Cánovas, G. V. 2003. Edible coatings composed of methylcellulose, stearic acid, and additives to preserve quality of pear wedges. Journal of Food Processing and Preservation, 27(4): 299320.

Oms-oliu, G., Soliva-fortuny, R., Martı, O., \& Rojasgrau, M. A. 2009. Review The use of packaging techniques to maintain freshness in fresh-cut fruits and vegetables : a review. 875-889.

Raghav, P. K., Agarwal, N., Saini, M., Vidhyapeeth, J., \& Vidhyapeeth, J. 2016. Edible Coating of Fruits and Vegetables : I Nternational Journal of Scientific and Modern Education, January. 1(1): 188-214Salem, T. N., \& Kassem, A. M. (2018). Nonlinear finite element analysis of foundations on preloaded soft ground. ISRM International Symposium 2000, IS 2000, 30(1), 35-38.

Suriati, L., Mangku, I. G. P., \& Rudianta, I. N. (2018). The characteristics of Aloe vera gel as an edible coating. IOP Conference Series: Earth and Environmental Science, 207(1):1-6.

Suriati, L., Utama, I. M. S., \& Suardani, A. 2020b. Edible Coating Base on Aloe Gel with Additives on Strawberry Fruit. SEAS (Sustainable Environment Agricultural Science), 04(01): 18-25.

Suriati, ., Utama, I. M. S., Harjosuwono, B. A., \& Gunam, I. B. W. 2020c. Incorporating additives for stability of Aloe gel potentially as an edible coating. AIMS Agriculture and Food, 5(3): 327-336. 